LWSA

Local Wisdom, Social, and Arts

PAPER - OPEN ACCESS

\title{
Gambaran Penerimaan Diri Ibu Tiri yang Memiliki Anak Tunarungu
}

\author{
Author \\ DOI \\ : Debby A Daulay \\ Electronic ISSN \\ : 10.32734/lwsa.v1i1.225 \\ Print ISSN \\ : 2654-7058 \\ : 2654-7066
}

Volume 1 Issue 1 - 2018 TALENTA Conference Series: Local Wisdom, Social and Arts

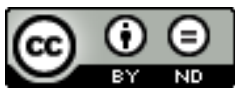

This work is licensed under a Creative Commons Attribution-NoDerivatives 4.0 International License.

Published under licence by TALENTA Publisher, Universitas Sumatera Utara
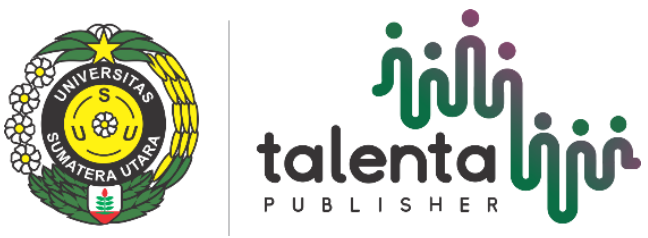


\title{
inili talentaliọ TALENTA Conference Series \\ P U B L I S H E R Available online at https://talentaconfseries.usu.ac.id \\ Gambaran Penerimaan Diri Ibu Tiri yang Memiliki Anak Tunarungu
}

\author{
Debby A. Daulaya ${ }^{\mathrm{a}}$, Rizqi Chairiyah ${ }^{\mathrm{a}}$ \\ ${ }^{a}$ Fakultas Psikologi, Universitas Sumatera Utara \\ debby_anggraini@usu.ac.id
}

\begin{abstract}
Penelitian ini bertujuan untuk mengetahui gambaran penerimaan diri ibu tiri yang memiliki anak tunarungu. Status ibu tiri yang umumnya memiliki penilaian negatif di masyarakat membuat ibu tiri membutuhkan proses adaptasi lebih, untuk pada akhirnya mampu menerima status diri, keadaan keluarga maupun kondisi anak tirinya yang mengalami ketunarunguan. Anak tuna rungu, dengan segala keterbatasan yang dimiliki khususnya dari segi bahasa dan lisan sudah barang tentu membutuhkan perhatian_ekstra' baik dari orang tua ataupun orang-orang disekitar yang turut berperan dalam proses pengasuhannya. Berkaitan dengan sejumlah kompleksitas dalam menyandang status sebagai ibu tiri yang harus mengasuh anak dengan kondisi tuna rungu, maka akan menjadi sangat menarik untuk melihat gambaran dinamika dari proses penerimaan diri ibu tiri tersebut. Adapun teori yang digunakan dalam penelitian ini adalah teori penerimaan diri dari Jersild (1963). Penerimaan diri adalah derajat dimana individu memiliki kesadaran terhadap karakteristiknya, sehingga diharapkan ia mampu dan bersedia untuk hidup dengan karakteristik tersebut. Penelitian ini menggunakan metode penelitian kualitatif dengan pendekatan studi kasus intrinsik. Melibatkan 2 orang partisipan dengan menggunakan teknik pengambilan partisipan berdasarkan theory-based operational construct sampling. Teknik pengambilan data yang digunakan adalah metode wawancara dan observasi. Hasil penelitian menunjukkan bahwa kedua partisipan memiliki penerimaan diri yang baik terhadap statusnya sebagai ibu tiri.Dalam hal ini, pemikiran positif dan realistik ternyata memiliki pengaruh yang besar terhadap proses penerimaan diri pada partisipan 1 maupun partisipan 2 berjalan secara lebih baik. Partisipan 1 telah menerima status dirinya sebagai ibu tiri yang memiliki anak tunarungu dan mampu menjalani kesepuluh aspek penerimaaan diri dengan baik. Tidak jauh berbeda, partisipan 2 juga telah memiliki penerimaan diri yang baik terhadap statusnya sebagai ibu tiri dan mampu menjalani kesembilan aspek penerimaan diri dengan baik. Adapun aspek yang tidak terpenuhi pada partisipan 2 yaitu _penerimaan yang baik dari orang lain'. Partisipan 2 belum bisa menerima dan menganggap anak tirinya yang tunarungu sebagai anaknya sendiri, dikarenakan faktor-faktor eksternal yang dalam hal ini adalah perilaku kasar dari anak tirinya tersebut serta adanya penolakan dari ibu mertua terhadap dirinya.
\end{abstract}

Kata Kunci: Ibu Tiri, Anak Tunarungu, Penerimaan Diri

\section{Latar belakang}

Berakhirnya suatu pernikahan, tidak jarang membuat seorang duda memutuskan untuk menikah lagi untuk mencari peran pengganti istri ataupun ibu untuk mengurus kehidupannya dan kehidupan anak-anaknya (Agnes, 2010). Adanya ikatan pernikahan yang baru ini,akanmemunculkan peran ibu pengganti yaitu ibu tiri (Arnee, 2013). Ibu tiri adalah 
seorang wanita yang dinikahi oleh ayah kandung setelah ayah kandung tidak memiliki ikatan pernikahan dengan ibu kandung, baik karena perpisahan maupun kematian (Beer dalam Zanden,1997).

Fenomena tentang karakteristik ibu tiri yang kejam, jahat, serta tidak perhatian terhadap anak bawaan dari suaminya, memang sudah sejak jaman dahulu berkembang dalam kehidupan bermasyarakat. Pandangan negatif pada ibu tiri tersebut, muncul dari legenda serta pandangan masyarakat yang mengembangkan cerita-cerita negatif dalam kehidupan bermasyarakat, sehingga hal ini seringkali membuat status ibu tiri menjadi bahan pembicaraan yang kurang baik di dalam masyarakat (Swari, 2012).Pada awalnya, kedatangan orang tua tiri seringkali dipandang sebagai hal yang negatif, namun sebenarnya orang tua tiri dapat menyediakan dukungan dan keamanan bagi keluarga orang tua tunggal. Oleh karena status ibu tiri yang sering dipandang sebagai hal yang negatif, membuat para wanita yang menyandang peran iniberupayamenyesuaikan diri agar bisa menerima dirinya dengan status tersebut (Agnes, 2010).

Salah satu kondisi yang dirasakan berbeda dan tentunya membutuhkan penyesuaian khusus antara lainadalah ketika menghadapi kondisi anak tiri yang berkebutuhan khusus. Ketika orang tua mengetahui bahwa anaknya mengalami suatu kondisi kecacatan tertentu, tentu ia akan menunjukkan berbagai reaksi emosi seperti cemas, sedih khawatir, takut, serta marah (Safaria, 2005). Begitu juga yang dialami oleh ibu tiri ketika ia menghadapi dan menerima kondisi anak tiri yang berkebutuhan khusus, maka ibu tiri akan merespon serta memiliki persepsi yang berbeda-beda pula. Salah satu yang termasuk anak berkebutuhan khusus dengan masalah fungsi indera adalah tunarungu.

Anak tunarungu merupakan anak yang memiliki gangguan pada pendengarannya, sehingga tidak dapat mendengar bunyi dengan sempurna atau bahkan tidak dapat mendengar sama sekali(Hallahan dan Kauffman, 1988). Adanya keterbatasan dalam bahasa dan komunikasi pada anak tunarungu, membuat anak tunarungu mengalami kesulitan untuk menyampaikan keinginan, perasaan ataupun ide-ide yang dimilikinya (Mangunsong, 2009). Berbeda halnya dengan anak berkebutuhan khusus lainnya seperti anak tunanetra, yang masih mampu berkomunikasi untuk menyampaikan keinginan, perasaan ataupun ide-ide yang dimilikinya karena masih mampu untuk mendengar dan berbicara seperti anak normal pada umumnya. Selain itu, anak tunarungu umumnya juga tidak dapat menggunakan pendengarannya untuk dapat mengartikan pembicaraan, walaupun sebagian pembicaraan dapat diterima dengan alat bantu mendengar (Soemantri, 2006). Umumnya, hambatan yang paling sering ditemui pada orang tua yang mengasuh anak tunarungu adalah kurangnya pemahaman atau pengetahuan orang tua tentang anak tunarungu, sehingga dengan segala keterbatasan yang ditunjukkan anak dapat memicutimbulnya sikap yang kurang sabar dalam mengasuh anak tunarungu tersebut(Heward, 1996). Adanya berbagai tantangan dan hambatan yang harus dijalani dan dihadapi untuk menjadi ibu tiri yang memiliki anak tunarungu, maka ibu tiri harus berusaha menerima dirinya untuk menjalani kehidupan dengan status tersebut serta mengasuh anak tirinya dengan segala keterbatasan yang dimilikinya.

Penerimaan diri adalah derajat dimana individu memiliki kesadaran terhadap karakteristiknya, sehingga ia mampu dan bersedia untuk hidup dengan karakteristik tersebut (Jersild, dalam Hurlock 1978).Individu yang menerima dirinya sendiri adalah individu yang memiliki keyakinan akan standar-standar dan pengakuan terhadap dirinya tanpa terpaku pada pendapat orang lain dan memiliki perhitungan akan keterbatasan dirinya (Jersild, 1963). Jadi ibutiridapat dikatakan memiliki penerimaan diri yang baik, ketika ia memiliki keyakinan bahwa status ibu tiri bukanlah hal yang negatif, serta ia tidak terpaku pada pandangan ataupun pendapat orang lain mengenai status ibu tiri tersebut. Pada dasarnya, penerimaan diri adalah sebuah proses (Jersild,1963). Hal ini dijelaskan oleh Jersild (1963), melalui beberapa aspek penerimaan diri yaitu, persepsi mengenai diri dan sikap terhadap penampilan; sikap terhadap kelemahan dan kekuatan diri sendiri dan orang lain; mampu mengatasi perasaan inferioritas; respon yang baik atas penolakan dan kritikan; keseimbangan antara real self dan ideal self; memiliki penerimaan diri dan penerimaan orang lain; menerima diri, menuruti kehendak dan menonjolkan diri; menerima diri, spontanitas, menikmati hidup; kejujuran dalam penerimaan diri, serta sikap yang baik terhadap penerimaan diri.

Berdasarkan uraian diatas, proses penerimaan diri akan dapat berjalan lebih baik, ketika individu memiliki harapan dan pandangan yang realistis terhadap keadaannya. Individu juga memiliki keyakinan akan standar-standar yang dimilikinya tanpa terpaku pada pendapat orang lain, serta dapat menerima kekurangan dan kelebihan di dalam dirinya (Jersild, 1963). Setiap individu akan memiliki cara-cara tersendiri dalam menerima dirinya. Hal ini juga terjadi pada ibu tiri yang memiliki anak tunarungu.

Melalui penelitian ini, peneliti juga ingin mengetahui lebih dalam tentang bagaimana proses penerimaan diri ibu tiri yang dihadapkan dengan kondisi anak tunarungu. 


\section{Tujuan}

Tujuan penelitian ini adalah untuk mengetahui gambaran penerimaan diri ibu tiri yang memiliki anak tunarungu.

\section{Metode}

Penelitian ini menggunakan pendekatan kualitatif dengan tipe penelitian studi kasusintrinsik.Tipe penelitian studi kasus digunakan sesuai dengan fokus penelitian yakniingin mengetahui gambaran penerimaan diri ibu tiri yang memiliki anak tunarungu.

a. Partisipan

Partisipan dalam penelitian ini berjumlah 2 orang ibu tiri yang memiliki anak tunarungu. Ibu tiri yang terlibat didalam penelitian ini haruslah terlibat langsung dalam merawat dan mengasuh anak tirinya yang tunarungu, agar dapat mengetahui hambatan dan tantangan yang dihadapi ibu tiri ketika mengasuh anak tunarungutersebut. Partisipan dipilih menggunakan teknik pengambilan partisipan berdasarkan

teori ataukonstruk operasional (theory-basedoperational construct sampling).

b. Metode Pengumpulan Data

Pengumpulan data pada penelitian ini menggunakan metode wawancara mendalam sebagai metode utama dan observasi sebagai metode pendukung. Alat bantu pengumpulan data pada penelitian ini adalah pedoman wawancara, pedoman observasi dan tape recorder. Pedoman wawancara disusun berdasarkan teori penerimaan diri.

\section{Hasil}

Penelitian ini melibatkan 2 orang partisipan yang memiliki status sebagai ibu tiri yang memiliki anak tunarungu. Partisipan 1 adalah seorang ibu tiri berusia 24 tahun yang telah menjalani hidupnya selama 2 tahun terakhir sebagai ibu tiri yang memiliki anak tunarungu. Partisipan 2 adalah seorang ibu tiri berusia 32 tahun yang telah menjalani hidupnya selama 6 tahun terakhir sebagai ibu tiri yang memiliki anak tunarungu.

Partisipan 1

Berdasarkan pengalaman partisipan 1 dalam menerima dirinya menjadi ibu tiri yang memiliki anak tunarungu, pemikiran yang realistik serta pemikiran positif adalah unsur yang berperan dalam proses penerimaan dirinya. Partisipan tidak penah memandang negatif terhadap status ibu tiri dan kondisi anak tunarungu. Partisipan juga dapat menyadari keadaannya saat ini dengan apa adanya dan tidak terpaku pada penilaian orang lain. Dampak dari penerimaan dirinya, yaitu partisipan merasa ikhlas dan dapat menikmati hidupnya saat ini tanpa harus terpaku pada statusnya sebagai ibu tiri yang memiliki anak tunarungu. Partisipan menerima dan tidak malu dengan statusnya sebagai ibu tiri yang memiliki anak tunarungu. Ia juga tidak kesulitan untuk berinteraksi dengan lingkungan sosialnya meskipun dirinya adalah seorang ibu tiri yang memiliki anak tunarungu.

Partisipan 2

Pada kasus partisipan 2, semenjak menjadi ibu tiri yang memiliki anak tunarungu partisipan sudah merasa ikhlas dalam menjalani kehidupannya dengan peran dan statusnya tersebut. Selain itu status pekerjaan partisipan sebagai ibu kepala lingkungan, menuntutnya untuk bisa bergabung dengan warga di lingkungannya. Dengan status ibu tiri yang dimilikinya, partisipan tidak merasa malu ketika berkumpul dengan warga di lingkungannya. Partisipan tetap merasa percaya diri ketika berinteraksi maupun berkumpul dengan tetangga dan warga di lingkungannya.Partisipan juga berusaha untuk tetap menikmati hidupnya tanpa harus memikirkan statusnya maupun penolakan dirinya oleh ibu mertuanya. Selain itu, partisipan tetap menikmati hidupnya tanpa harus memikirkan penilaian umum masyarakat mengenai karakteristik ibu tiri yang kejam. Dampak dari penerimaan diri partisipan selama 6 tahun ini, yaitu partisipan sudah merasa ikhlas lahir batin meskipun partisipan belum sepenuhnya mampu menganggap anak tirinya sebagaimana anaknya sendiri. Partisipan mengatakan bahwa Tuhan sudah memberikan jalan terbaik bagi dirinya untuk menjalani hidup sebagai ibu tiri yang memiliki anak tunarungu. Oleh karena itu, partisipan sudah menerima dan mengikhlaskan takdir yang diberikan Tuhan kepadanya. 


\section{Diskusi dan Kesimpulan}

Kedua partisipan dapat disimpulkan mampu menjalani proses penerimaan diri dengan baik terhadap statusnya sebagai ibu tiri. Namun ada perbedaan antara partisipan 1 dan partisipan 2 dalam menerima dirinya sebagai ibu tiri yang memiliki anak tunarungu. Partisipan 1 merasa lebih mudah untuk menerima dirinya sebagai ibu tiri dan merasa mudah dalam menerima kondisi anak tirinya yang tunarungu. Adanya dukungan dari keluraga dan orang-orang terdekat, membuat partisipan 1 tidak mengalami hambatan yang berarti dalam menerima statusnya tersebut. Partisipan 1 mampu menjalani kesepuluh aspek penerimaan diri (Jersild, 1963) dengan baik. Pada partisipan 2, ia hanya bisa menerima dirinya sebagai ibu tiri dan sampai saat ini belum bisa menerima anak tirinya yang tunarungu sebagai anaknya sendiri. Partisipan 2 hanya mampu menjalani kesembilan aspek penerimaan diri (Jersild, 1963) dan belum memiliki penerimaan orang lain dengan baik.

Pemikiran positif dan pemikiran realistik adalah unsur yang berperan dalam proses penerimaan diri pada partisipan 1. Bagi partisipan 1, hal terpenting saat ini adalah menjalankan perannya sebagai ibu tiri yang merawat dan mengasuh anak tirinya seperti ibu kandung yang mengasuh anak tunarungu seperti keluarga normal pada umumnya. Partisipan 1 sudah merasa cukup ikhlas dan juga tidak merasa malu dengan statusnya tersebut. Rasa sabar yang dimiliki oleh partisipan 1 juga turut berperan dalam proses penerimaan dirinya. Pada partisipan 2, pemikiran positif dan dukungan sosial sangat berpengaruh terhadap proses penerimaan dirinya. Partisipan 2 telah mampu menerima statusnya sebagai ibu tiri, namun dirinya merasa belum bisa menerima anak tirinya yang tunarungu sebagai anaknya. Saat ini yang menjadi perhatian pada partisipan 2 adalah bagaimana ia mampu merubah perilaku kasar anak tirinya dan bagaimana agar ibu mertuanya dapat menerima dirinya sebagai menantunya. Sampai saat ini, partisipan 2 merasa belum mendapatkan dukungan dari ibu mertuanya mengenai pernikahan dan statusnya. Dukungan sosial yang tidak didapatkannya dari ibu mertuanya, tidak membuat partisipan 2 berhenti mengasuh dan merawat anak tirinya. Adanya dukungan dari suaminya, membuat partisipan 2 mampu bertahan dalam menjalani rumah tangganya. Saat ini, partisipan 2 sudah merasa ikhlas lahir batin dalam menjalani hidupnya dan menghadapi perlakuan dari ibu mertuanya. Rasa sabar yang ada pada partisipan 2 juga turut berperan dalam proses penerimaan dirinya.

Berdasarkan hasil penelitian yang telah dilakukan, ditemukan bahwa kedua partisipan pernah terpengaruh dengan penilaian umum masyarakat mengenai karakteristik ibu tiri yang kejam. Meskipun kedua partisipan memiliki penerimaan diri yang baik sebagai ibu tiri, namun kedua partisipan memiliki caranya tersendiri dalam menerima dirinya sebagai ibu tiri yang memiliki anak tunarungu. Implikasi dari penelitian ini kepada partisipan 1 yaitu partisipan harus mampu membagi waktunya untuk mengasuh dan memperhatikan kondisi anak tirinya yang tunarungu. Dikarenakan kondisi ketunarunguannya,anak tentu membutuhkan pelayanan dan perhatian khusus dari partisipan, bukan dari orang lain. Partisipan juga diharapkan memperhatikan pendidikan dan sekolah khusus bagi anak tirinya yang mengalami tunarungu. Sementara, implikasi untuk partisipan 2 yaitu partisipan diharapkan dapat lebih sabar dan mampu untuk mengontrol rasa emosi sesaat dalam menghadapi perlakuan negatif dari anak tiri dan ibu mertuanya. Hal ini bertujuan agar kondisi ini jangan sampai mempengaruhi proses pengasuhan serta mampu memperbaiki hubungannya dengan ibu mertua. Partisipan juga diharapkan untuk memperhatikan cara pengasuhan yang lebih sesuai, agar anak tirinya secara perlahan dapat merubah perilaku kasarnya. Hal ini dapat dilakukan melalui kerja sama dengan suami dalam mengasuhnya.

Penelitian ini masih jauh dari kesempurnaan,sehingga untuk penelitian selanjutnya diharapkan dapat memperhatikan faktor kepribadian dalam proses penerimaan diri. Penelitian selanjutnya juga diharapkan dapat mengukur aspek lain yang dapat lebih mengungkapkan kehidupan ibu tiri dalam konteks psikologi, seperti social support,emotional bounding, interaksi sosial dan lain sebagainya.

\section{References}

[1] Agnes, Yurika. (2010). Pencapaian Identitas Diri Remaja yang Memiliki Ibu tiri. Skripsi. Depok: Psikologi Universitas Gunadarma.

[2] Ahira, Anne (2009).Anak Berkebutuhan Khusus. [Online]. http://www.anneahira.com/anak- berkebutuhan-khusus.htm. Diakses tanggal Juli 2014

[3] Chumar (2012). Ibu tiri dan Ibu Angkat. http://cimengayan.blogspot.com/p/ibu-tiri-dan-ibu-angkat.html[Online]. Diakses tanggal 22 November 
[4] Hallahan, D. P \& Kauffman, J. M. (1988). Exceptional Children : An introduction to special education (4th Ed). New Jersey: Prentice - Hall

[5] Heward, W. L. (1996). Exceptional Children : An introduction to special education (5th Ed). New Jersey: Prentice - Hall Inc.

[6] Hurlock, E.B. 1978. Developmental Psychology. Edisi 4. New Delhi: Tata McGraw Hill.

[7] Hurlock, E.B. (1980). Psikologi Perkembangan : Suatu Pendekatan Sepanjang Rentang Kehidupan.

[8] Jersild, A.T. (1963). The Psychology of Adolescence. New York : MC Millan Company.

[9] Mangunsong, F. 2009. Psikologi dan Pendidikan Anak Berkebutuhan Khusus, Jilid Kesatu. Jakarta: Lembaga Pengembangan Sarana Pengukuran dan Pendidikan Psikologi (LPSP3).

[10] Papalia, D. E., Olds, S. W., \& Feldman, R. D. (2001). Human development (8th eds.). Boston: McGraw- Hill.

[11] Poerwandari, Kristi. (2005). Pendekatan Kualitatif untuk Penelitian Perilaku Manusia. Jakarta: LPSP3 Fakultas Psikologi Universitas Indonesia

[12] Poerwandari, Kristi. (2007). Pendekatan Kualitatif untuk Penelitian Perilaku Manusia. Jakarta: LPSP3 Fakultas Psikologi Universitas Indonesia

[13] Soemantri, Sutjihati.2006. Psikologi Anak Luar Biasa. Jakarta: Refika Aditama

[14] Swari, Intan. 2012. Ibu Tiri. [Online] http://intand14kiiroi.blogspot.com/2012/07/ibu-tiri.html. Diakses tanggal 11 Oktober 2013

[15] Zanden, J. W. V. (1997). Human Development. (7th ed.). New York: McGraw Hill, Inc. 